\title{
The Urgency of Civic Education and Religious Character Education for Early Childhood in Indonesia
}

\author{
Choirul Mahfud, Niken Prasetyawati, Dyah S.Y Agustin, \\ Ni Wayan Suarmini, Enie Hendrajati \\ Institut Teknologi Sepuluh Nopember Surabaya \\ Jl. Raya ITS, Keputih, Kec. Sukolilo, Kota SBY, Jawa Timur 60111 \\ choirul.mahfud@its.ac.id,dyah@mku.its.ac.id,nikenprasetyawati@gmail.com, \\ mini.wayan@gmail.com, enie@mku.its.ac.id
}

Accepted: 15 June 2019

\begin{abstract}
The urgency and relevance of civic education and religious character education from an early age has several challenges as well as opportunities. The research in this paper is qualitative with an analytical descriptive approach using documentation methods. The general objective of this study is to understand not only the urgency but also the relevance of citizenship education and religious character education from an early age in Indonesia? What are the challenges and opportunities for implementing civic education and religious character education for an early age in Indonesia? In general, strengthening civic education and religious character education from an early age in Indonesia is still important because this is part of a process that has never been completed. This is relevant to the spirit of change and sustainability from era to era. In this case, the challenges can be said to be not small. More than that, the opportunity may also be greater to be optimized for the realization of unity in diversity and the progress of the nation.
\end{abstract}

Keywords: Civic Education, Character Education, Early Childhood

\begin{abstract}
Abstrak
Urgensi dan relevansi pendidikan kewarganegaraan dan pendidikan karakter religius sejak usia dini memiliki sejumlah tantangan sekaligus peluang. Penelitian dalam tulisan ini bersifat kualitatif dengan pendekatan deskriptif analitis dengan menggunakan metode dokumentatif. Tujuan umum penelitian ini adalah untuk memahami tidak hanya mengenai urgensi tetapi juga relevansi pendidikan kewarganegaraan dan pendidikan karakter religius sejak usia dini di Indonesia? Bagaimana tantangan dan peluang implementasi pendidikan kewarganegaraan dan pendidikan karakter religius untuk usia dini di Indonesia? Secara umum, penguatan pendidikan kewarganegaraan dan pendidikan karakter religius sejak usia dini di Indonesia masih penting dilanjutkan karena hal ini merupakan bagian
\end{abstract}


dari proses yang tidak pernah selesai. Hal ini relevan dengan semangat perubahan dan keberlanjutan dari era ke era. Dalam hal ini, tantangannya bisa dikatakan tidak sedikit. Lebih dari itu, peluangnya boleh dikatakan juga lebih besar untuk dioptimalkan demi terwujudnya unity in diversity dan kemajuan bangsa.

Kata Kunci: Pendidikan Kewarganegaraan, Pendidikan Karakter, Anak Usia Dini.

\section{Introduction}

Research on civic education and religious character education for early childhood in Indonesia is something that is still important to be aware of. ${ }^{1}$ The main reason that early childhood is the golden age. If all good is taught from the beginning, then finally it will be better. This includes related values in citizenship education and religious character

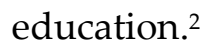

We understand that good family education, usually, also provides good education regarding good manners, ethics, and culture. Conversely, if you are not accustomed to good behavior from an early age, it is possible to expect good results from an early age generation. It is also difficult to expect. Therefore, early childhood education should continue to be considered in maintaining a relationship with the life of society and the nation.

In this context, the focus of research in this paper see more clearly about the problems in the implementation of civic education and religious character

\footnotetext{
${ }^{1}$ Doni A. Kusuma, Pendidikan Karakter (Jakarta: Grasindo, 2007), 19-27.

2 AM Albantani and A. Madkur, Integrating character education values in language teaching: why and how, a paper presented in The 4th ELITE International Conference, 400-414, (2016).
}

education for early childhood in Indonesia. The hope is that there is a better understanding of the issue of citizenship, Pancasila and religious character education in Indonesia. ${ }^{34}$

From the background of this problem, this study focuses on the following important questions: What are the urgency of civic education and religious character education for early childhood in Indonesia? What is the relevance of civic education and religious character education in Indonesia? What are the challenges and opportunities for implementing civic education and religious character education for early childhood in Indonesia.

\section{Method}

In this study, the qualitative research method used is a descriptive method that can be interpreted as a research procedure that focuses on words rather than numbers to explain the object of research. ${ }^{5}$ In this regard could be related persons, institutions, communities and others which are now based on the facts

\footnotetext{
${ }^{3}$ A. Azra, Pancasila dan Identitas Nasional Indonesia (Bogor: Brighten Press, 2006).

${ }^{4}$ Mochtar Buchori, Pendidikan Antisipatoris (Yogyakarta: Kanisius, 1994), 8-11.

5 Lexy J. Moleong, Metodologi Penelitian Kualitatif (Bandung: P.T. Remaja Rosda Karya, 2002), 17-20.
} 
that appear or what it is. Through descriptive data, researchers are able to identify why, what and how social phenomena, education occurs or is implemented. In general, the main objectives of the descriptive research method are three: describing, explaining, and validating the research findings conducted to obtain a conclusion or research results.

\section{Discussion}

Before discussing more details, here need to be explained more about what is civic education and religious character education. In general, civic education is education or lessons that teach the importance of the values of the rights and obligations of a citizen, with the aim that every thing that were done it could be consistent with the objectives and ideals of the nation and not to deviate from what which are expected. Because this citizenship education is very important, this citizenship education has been implemented starting from an early age at every level of education starting from the earliest to the tertiary level.

In a different definition, John J. Cogan (1999) distinguishes the term citizenship education into two senses; Civic education and Citizenship education/ Education for citizenship. ${ }^{6}$ According to him, Civic education is citizenship education in a narrow sense that is as a form of formal education, such as subjects and courses and courses in

6 Cogan \& Derricott. Citizenship Education for 21 st Century (London: Kogan Page, 1998), 111-118. school institutions/ universities or other formal institutions.

While citizenship education does not only cover formal forms of civic education but also informal and nonformal forms of civic education. ${ }^{7}$ These informal or non-formal forms can be in the form of upgrading programs or other programs that are deliberately designed to facilitate the process of maturation or maturation as good and intelligent citizens. So citizenship education has a general and broad meaning.

The results of the study from the Center For Indonesian Civic Education (CICED) revealed that what is meant by citizenship education is a transformation process that helps build heterogeneous communities into a single unit of Indonesian society, develops Indonesian citizens who have knowledge and trust in God, have a high awareness of rights and obligations, legal awareness, political sensitivity, political participation, and civil society".

In accordance with the new paradigm of citizenship education, where students (students) are also directed to have civic knowledge competencies (civics knowledge), civics skills, and civics value as well as later life skills, especially life skills in the personal, social and intellectual fields. One component that goes into in citizenship skills are intellectual skills, namely skills related to mastery of citizenship subject matter which includes study or discussion of the state, citizens,

${ }^{7}$ John Barndsford, How People Learn (Washington DC: National Academy Press, 2000). Also, Bestari, Prayoga. Memahami Hak Asasi Manusia. (Bandung: Laboratorium Pendidikan Kewarganegaraan UPI, 2013), 99. 
relations between the state and its citizens, the rights and obligations of the state and citizens, matters of government, law, politics, moral, and so on. ${ }^{8}$ Whereas intellectual skills mean the skills, willingness, or capabilities of human beings concerning cognitive aspects, not physical aspects of movement (psychomotor) or attitudes (Ministry of National Education, 2003).

Citizens who understand and master the knowledge of citizenship and values of citizenship will become citizens who have confidence. Also, citizens who understand and master citizenship knowledge will become citizens who are knowledgeable and personable. In this context, it can be said that successful citizenship education will be able to produce a smart mental attitude and full of responsibility, this attitude is accompanied by behavior that: a). Faith \& Faith in God Almighty and appreciate the values of the nation's philosophy. $b$ ). Noble character, disciplined in the nation \& state. c). Rational, dynamic \& patient about the rights and obligations of citizens. d). Professional in nature, inspired by the awareness of defending the country. e). Actively utilizing science, technology, and art for the benefit of humanity, nation and state.

In general, the substance of the study of citizenship education is: 1 . Dimensions of civics knowledge. Includes political, legal and moral fields. In detail citizenship education material includes knowledge of the principles and

8 Kansil \& Kansil. Empat Pilar Berbangsa dan Bernegara (Jakarta: Rineka Cipta, 2013). processes of democracy, government and non-government institutions, national identity, the government based on the rule of law and free and impartial justice, constitution, national history, human rights, rights civil, and political rights. 2 . Dimensions of civics skills. Includes skills to participate in the life of the nation and state, for example: participating and actively realizing civil society, political decision-making processes, skills to hold coalitions, cooperation, managing conflict, life skills and so on. 3. Dimensions of civics values. Includes confidence, commitment, mastery of religious values, norms, and noble values, values of justice, democracy, tolerance, individual freedom, freedom of speech, freedom of the press, freedom of association and assembly, protection of minorities and so on. ${ }^{9}$

These dimensions can not stand alone and is a unified whole and round, because citizenship education is seen as the subjects that play an important role in shaping the good citizen, morals, and is responsible in accordance with the philosophy and the RI Constitution.

The content of subjects in citizenship education is to realize an integral educational process in schools for the development of intelligent, participatory and responsible abilities and personalities which in turn will become the foundation for the development of a democratic Indonesian society. Based on the vision of citizenship education subjects, the mission of citizenship education

${ }^{9} \mathrm{~K}$. Yahiji, Mahfud, Vocational Education in Indonesia Facing ASEAN Economic Community. Indonesian Research Journal in Education |IRJE|, v. 3, n. 1, p. 168-176, 16 jun. 2019. 
subjects can be developed as follows: 1 ). Developing a new frame of mind that can be used as a rational basis for arranging citizenship education as intellectual education towards the formation of democratic citizens. 2). Arrange the substance of citizenship education as a democratic education based on sociocultural background and in the political context, statehood, and constitutional foundation as outlined in the pillars of Indonesian democracy.

In this case, the function of citizenship education functions as a vehicle for forming intelligent, skilled and character citizens who are loyal to the Indonesian nation and state by reflecting themselves in the habit of thinking and acting in accordance with the mandate of the Indonesian Constitution. ${ }^{10}$

In addition to the definition of citizenship education, here also needs to be explained also about the definition of religious character education. Religious character education is the three words that have been the subject of much discussion in the world of education lately. ${ }^{11}$ Where its existence is integrated in the 2013 curriculum. Character education which consists of five values, namely: religious, nationalism, independence, mutual cooperation, and

\footnotetext{
10 Rahmat et al. Pembelajaran Pendidikan Kewarganegaraan (Bandung: Laboratorium Pendidikan Kewarganegaraan UPI, 2009). And, Suwarma Al Muchtar dkk. Strategi Pembelajaran PKn. (Jakarta: Universitas Terbuka, 2007), 19-37.

${ }^{11}$ Thomas Lickona, Character Matters (Jakarta: PT. Bumi Aksara, 2012), 38-45.
}

integrity are the main pillars to be formed in students. ${ }^{12}$

The word "religious" has been more synonymous with religious education institutions such as the Elementary Madrasah, Madrasah Tsanawiyah, Madrasah Aliyah, and integrated Islamic schools. Now no longer after character education began to be applied in public schools. Is that religious? Quoting from Ernsnaw, religion is a way of looking at someone about his religion and how that person uses his beliefs or religion in his daily life. Religious character is synonymous with religious behavior so that it contains positive values. Therefore religious character becomes the initial capital to form other characters. ${ }^{13}$

What kind of religious character would you like to form for students? The Ministry of Environment explains that there are five religious aspects of Islam. Namely: aspects of faith, aspects Islam, aspects of ikhsan, aspects of science, and aspects of charity. These aspects are implemented for students both in theory and practice. How is the theory of religious character given in the school? The main thing is during teaching and learning activities in Islamic Education (PAI) subjects. As a supporter, a morning lecture given outside of school hours can be held on Sunday mornings.

The question is, how does the practice of religious character take place at

12 Abdul Majid, Dian Andayani, Pendidikan Karakter Perspektif Islam (Bandung: PT Remaja Rosdakarya, 2011. Also, Akhmad Muhaimin Azzet, Urgensi Pendidikan Karakter di Indonesia (Yogyakarta: Ar-Ruz Media, 2011).

${ }^{13}$ Anas Salahudin, Pendidikan Karakter Pendidikan Berbasis Agama dan Budaya Bangsa (Bandung: CV. Pustaka Setia, 2013). 
school? Namely with habituation models, can be daily or weekly. Examples of daily habituation are 3S (Smiles, Saying and Greetings), recitation of the Asmaul Husna prayer, and duha prayer a simple example of attitudes and actions that reflect religious character as follows: students are grateful for the results of their tests, visit their friends who are sick, help their friends who are affected. So that it is carried out in balance between religious worship with religious social.

The important thing is to make this religious character entrenched among female students both in the school and society. We as educators as well as parents must always be patient and enthusiastic in instilling the value of this religious character. We must always remind students of recommendations and prohibitions, tell inspiring stories from religious leaders and create a pleasant atmosphere of worship in the school environment. If this religious character has been formed strongly then the author believes that other character values will follow.

In accordance with President Joko Widodo's direction, character education at the level of basic education has a greater portion than education that teaches knowledge. For elementary schools, 70 percent, while for junior high schools, 60 percent. Minister of Education and Culture (Mendikbud) Muhadjir Effendy said that the Character Education Strengthening Movement is the main foundation and spirit of education. Not only does it think (literacy), national education to pay attention to the hearts (ethics and spiritual) of taste (aesthetics), and also sports (kinesthetic). The four dimensions of this education should be carried out as a whole and simultaneously. The integration of the intra-curricular, cocurricular, and extracurricular learning processes in schools can be carried out based on the development of school culture and through collaboration with communities outside the educational environment.

There are five main character values derived from Pancasila, which are the priorities for the development; namely religious, nationalism, integrity, independence and mutual cooperation. Each value does not stand up and develop individually but interact with each other, develop dynamically and form personal wholeness. The value of religious character reflects the belief in God Almighty which is manifested in the behavior of carrying out religious teachings and beliefs that are adhered to, respecting religious differences, upholding a tolerant attitude towards the implementation of other religious and belief services, living in harmony and peace with other religions. The implementation of the values of religious character is shown in the attitude of peace, tolerance, respect for differences in religion and belief, firm stance, self-confidence, cooperation between believers and religions, anti-abuse and violence, friendship, sincerity, not imposing the will, loving the environment, protecting small and marginalized.

Values of nationalist character shown by the attitude of the nation's own cultural appreciation, keeping the cultural wealth of the nation, sacrifice, excel, and excel, love of the homeland, protecting the 
environment, law-abiding, self-discipline, respect for cultural diversity, ethnicity, and religion. The character value of integrity is the underlying value of behavior based on efforts to make himself a person who can always be trusted in words, actions, and jobs has a commitment and loyalty to human and moral values. The character of integrity includes an attitude of responsibility as a citizen, actively involved in social life, through the consistency of actions and words based on truth. Someone who has integrity also respects the dignity of individuals (especially people with disabilities) and is able to demonstrate exemplary.

Independent character values are attitudes and behaviors that do not depend on others and use all energy, mind, time to realize hopes, dreams, and ideals. Independent students have a good, tough, fighting, professional, creative work ethic, courage, and become lifelong learners. And, the value of mutual cooperation character reflects the act of appreciating the spirit of cooperation and working together to solve common problems, establish communication and friendship, provide assistance/ assistance to those in need. It is expected that students can show respect for others, be able to work together, be inclusive, be able to commit to joint decisions, reach consensus, help, have empathy and a sense of solidarity, anti-discrimination, anti-violence, and an attitude of volunteerism.

According to the Minister of Education and Culture, the key to the success of character education lies in the

role of the teacher. Ideally, a teacher also has closeness with his students. Teachers should be able to stick with their students so they can know the development of their students. Not only the intellectual dimension but also the personality of each of their students. Not only as instructors of subjects, but teachers are able to act as facilitators who help students achieve learning targets. The teacher must also be able to act as a gatekeeper who helps students filter out various negative influences that have an adverse effect on their development. ${ }^{14} \mathrm{~A}$ teacher is also able to act as a liaison for students with a variety of learning resources that are not only in the classroom or school. And as a catalyst, teachers are also able to explore and optimize the potential of each student. ${ }^{15}$ At present, through the revision of Government Regulation Number 64 of 2008 to PP Number 19 of 2017, the Ministry of Education and Culture encourages changes in the paradigm of teachers to be able to carry out their role as professional educators who are not only able to educate students, but also shape their positive character to become Indonesia's golden generation with 21 st century skills.

\footnotetext{
${ }^{14}$ Gunawan Ikhtiono, “Al-Qur’an dan Implementasi Pendidikan Karakter Kewarganegaraan." Tarbawiyah Jurnal Ilmiah Pendidikan, [S.1.], v. 13, n. 02, p. 169-186, mar. 2017. Musyarrafah SulaimanKurdi, "Evaluasi Implementasi Desain Pendidikan Karakter Berbasis Pendekatan Humanistik." Elementary: Jurnal Ilmiah Pendidikan Dasar, [S.1.], v. 4, n. 2, p. 125-138, nov. 2018.

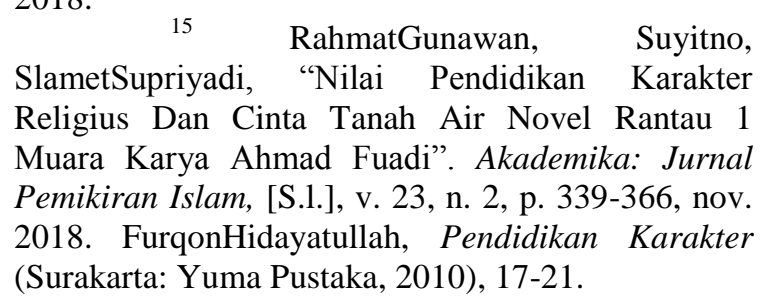


Based on Article 15 of Government Regulation Number 19 of 2017, the fulfillment of teacher workloads can be obtained from the equivalent workload of additional tasks. Other activities outside the classroom related to learning can also be converted to face-toface hours. According to the Minister of Education and Culture that Teachers no longer need to look for additional hours of teaching outside their schools to meet the teaching workload. He must be responsible for the development of his students.

In general, the objectives of character education are a. Encourage the habits and behavior of students who are commendable and in line with universal values and religious cultural traditions. $b$. Enhance the ability to avoid despicable qualities that can damage yourself, others and the environment. c. Cultivate the toughness and sensitivity of students to the surrounding situation so as not to fall into deviant behavior both individually and socially. $d$. Instill the leadership and responsibility of students as the nation's successor.

Importantly, why is civic education and religious character education still needed and important to be learned by early childhood in Indonesia? There are lots of answers and arguments. Minimally, because it is very important for early childhood to know and understand about the nation and state of Indonesia. Also they have become accustomed to being children who like to do good. If a good foundation has been planted since childhood, then he will grow well in the future. We as part of the
Indonesian nation also have a similar role to maintain and maintain the foundation of our country, Indonesia.

Therefore, giving a lesson for those from the small age to have a high sense of love for the homeland and having a high awareness to maintain the independence of Indonesia which has been championed by the heroes of the nation who succeeded in driving away the invaders, of course, all parties need to strive. But unfortunately, lately, lessons in civic education and religious character education are still often underestimated by many parties. In fact, Citizenship Education or often called PKN and religious character education are important lessons and must be given well to early childhood.

The introduction and implementation of the values of civic education and religious character education in the daily lives of early childhood is not only the responsibility of the teacher in the school. Parents should also give serious attention to the importance of the introduction of Pancasila and the application of Pancasila values at home. However, good experiences that have been instilled in early childhood should not be interrupted when the child enters elementary school (formal education). Planting values in the attitude of everyday life of early childhood must continue. The chain of religious character education that has been carried out in early childhood education institutions should be continued by educators in all forms of educational institutions. This is important to continue according to the weight of early childhood growth and development. 
With integrated learning early childhood can be invited to play while learning and learning while playing. For example, the cultivation of noble values reflected in Pancasila, civic education, religious character education can be taught to children through their attitudes and behavior. For example, divine values are introduced to children through prayer activities together in places of worship according to their respective religions. The value of togetherness which is the transfer of value of unity is introduced to children through games that highlight the importance of cooperation between them. That is a practical example of the application of civic education, religious character education for early childhood. If applied and introduced continuously, then the child will easily practice and apply in his life.

Challenges and opportunities for civic education and religious character education for early childhood in Indonesia, of course, can be understood from all aspects related to its implementation in the education provided by the government (formal), or also initiated by the non-government institution (non-formal) and even education at the family level (informal). This needs to continue to be a shared reflection for all.

\section{Conclusion}

The future of a nation is strongly influenced by the role of education. Specifically, the influence of civic education and religious character education has a major contribution to the progress of the nation and unity in differences that can be instilled from an early age. All parties need to take a role, starting from formal, non-formal and informal education institutions. Also, all stakeholders of education in Indonesia to realize the idealism of the nation in the world.

\section{References}

A. Kusuma, Doni, Pendidikan Karakter (Jakarta: Grasindo, 2007).

Albantani, AM dan Madkur, A., Integrating character education values in language teaching: why and how, a paper presented in The 4th ELITE International Conference, 400-414, (2016)

Azra, A. Pancasila dan Identitas Nasional Indonesia (Bogor: Brighten Press, 2006).

Barndsford, John. How People Learn (Washington DC: National Academy Press, 2000).

Bestari, Prayoga. Memahami Hak Asasi Manusia. (Bandung: Laboratorium Pendidikan Kewarganegaraan UPI, 2013).

Buchori, Mochtar. Pendidikan Antisipatoris. (Yogyakarta: Kanisius, 1994).

Cogan \& Derricott. Citizenship Education for 21st Century: Setting the Context. (London: Kogan Page, 1998).

Darmodihardjo et al. Santiaji Pancasila. (Surabaya: Usaha Nasional, 1988).

Delors, Jacques, et al. Learning: The Treasure Within, Report to UNESCO of the International Commissions on Education for the Twenty-first Century. (France: UNESCO Publishing, 1996).

Hidayatullah, Furqon, Pendidikan Karakter; Membangun Peradaban Bangsa, (Surakarta: Yuma Pustaka, 2010). 
J. Moleong, Lexy, Metodologi Penelitian Kualitatif, (Bandung: P.T. Remaja Rosda Karya, 2002).

Kesuma, Dharma, Pendidikan Karakter (Bandung: PT Remaja Rosdakarya, 2011).

Kurdi, Musyarrafah Sulaiman. "Evaluasi Implementasi Desain Pendidikan Karakter Berbasis Pendekatan Humanistik." Elementary: Jurnal Ilmiah Pendidikan Dasar, [S.1.], v. 4, n. 2, p. 125-138, nov. 2018.

Latif, Yudi. Negara Paripurna Historitas, Rasionalitas, dan Aktualitas Pancasila. (Jakarta: Gramedia Pustaka Utama, 2015).

Lickona, Thomas. Character Matters. (Jakarta: PT. Bumi Aksara, 2012).

Mahfud, Choirul. The Role of Islamic Education Teachers of Early Age In The Eradication of Illiteracy In Indonesia, Nur El-Islam: Jurnal Pendidikan dan Sosial Keagamaan 5 (1), 1-15, 2018. . Understanding Education of Authoritative Islamic Law Perspective Khaled Abou el Fadl, Modeling 6 (1), 1-12, 2019.

Majid, Abdul, Dian Andayani, Pendidikan Karakter Perspektif Islam, (Bandung: PT Remaja Rosdakarya, 2011.

Muhaimin Azzet, Akhmad, Urgensi Pendidikan Karakter di Indonesia,
(Yogyakarta: Ar-Ruz Media, 2011).

Muhibbin, Z., Mahfud, C, Penguatan Spiritualitas untuk Menghadapi Fenomena Dehumanisasi Akibat Teknologi Maju dan Industrialisasi, IPTEK Journal of Proceedings Series, 266-271, 2018.

Rahmat et al. Pembelajaran Pendidikan Kewarganegaraan. (Bandung: Laboratorium Pendidikan Kewarganegaraan UPI, 2009).

Rahmawati, Yahiji, Mahfud, Choirul, Alfin, Koiri, Chinese ways of being good Muslim: from the Cheng Hoo Mosque to Islamic education and media literacy, Indonesian Journal of Islam and Muslim Societies 8 (2), 225-252, 2018.

Samani, Muchlas, dkk, Pendidikan Karakter, (Bandung: PT Remaja Rosdakarya, 2012).

Suwarma Al Muchtar dkk. Strategi Pembelajaran PKn. (Jakarta: Universitas Terbuka, 2007).

Yahiji, K.; Mahfud, C.; Mu'ammar, M. Vocational Education in Indonesia Facing ASEAN Economic Community. Indonesian Research Journal in Education |IRJEI, v. 3, n. 1, p. 168-176, 16 jun. 2019.

Zubaedi, Desain Pendidikan Karakter; Konsepsi dan Aplikasinya dalam Lembaga Pendidikan, (Jakarta: Kencana, 2011). 